\title{
CONTABILIDADE SOCIETÁRIA X CONTABILIDADE REGULATÓRIA: VALUE RELEVANCE DAS INFORMAÇŌES CONTÁBEIS DO SETOR ELÉTRICO BRASILEIRO
}

\author{
Marília Paranaíba Ferreira ${ }^{1}$ \\ Alex Mussoi Ribeiro 2 \\ Jackelline Ferreira Cordeiro Milhomem ${ }^{3}$ \\ Carlos Henrique Silva do Carmo ${ }^{4}$
}

- Artigo recebido em: 15/06/2020 -- Artigo aceito em: 01/12/2020 -." Segunda versão aceita em: 14/01/2021

\section{RESUMO}

Nas empresas do setor de energia elétrica as demonstrações contábeis devem ser apresentadas conforme a Contabilidade Societária e a Contabilidade Regulatória. Sendo assim, esta pesquisa objetiva verificar, entre o modelo contábil societário e regulatório, qual melhor explica a variação do preço das ações das companhias elétricas brasileiras no período entre 2011 e 2018. As informações foram coletadas na base de dados da Economatica® e no sítio eletrônico da Agência Nacional de Energia Elétrica (ANEEL). A análise foi feita por meio de regressões múltiplas com dados em painel e os modelos foram estimados com base na metodologia de Collins, Maydew e Weiss (1997), desenvolvida a partir de Ohlson (1995). Os resultados apontaram que o modelo societário apresenta poder explicativo superior $\left(R^{2}\right.$ de $\left.65,39 \%\right)$ em comparação

1 Doutoranda em Contabilidade pela Universidade Federal de Santa Catarina (UFSC). Endereço: Rua Eng. Agronômico Andrei Cristian Ferreira, s/n - Centro Socioeconômico (CSE), sala 225, Trindade, Florianópolis-SC, CEP: 88040-970. Telefone: (48) 3721-6608. E-mail: mariliaferreira82@hotmail.com https://orcid.org/0000-0003-4290-8589

2 Doutor em Controladoria e Contabilidade pela Universidade de São Paulo (USP). Professor do Programa de Pós-Graduação em Contabilidade da Universidade Federal de Santa Catarina (UFSC). Endereço: Rua Eng. Agronômico Andrei Cristian Ferreira, s/n - Centro Socioeconômico, sala 115, Trindade, Florianópolis-SC, CEP: 88040-970. Telefone: (48) 37216608. E-mail: alex.mussoi@ufsc.br

https://orcid.org/0000-0003-3389-9713

3 Mestre em Contabilidade pela Universidade Federal de Goiás (UFG). Endereço: Rua Samambaia, s/n - Faculdade de Administração, Ciências Contábeis e Ciências Econômicas (FACE), Campus Samambaia, Goiânia-GO, CEP: 74001-970. Telefone: (62) 3521-1390 ramal 252. E-mail: jackelline.ufg@gmail.com https://orcid.org/0000-0002-9759-1729

${ }^{4}$ Doutor em Controladoria e Contabilidade pela Universidade de São Paulo (USP). Professor do Programa de Pós-Graduação em Contabilidade da Universidade Federal de Goiás (UFG). Endereço: Rua Samambaia, s/n - Faculdade de Administração, Ciências Contábeis e Ciências Econômicas (FACE), Campus Samambaia, Goiânia-GO, CEP: 74001-970. Telefone: (62) 3521-1390. E-mail: chscarmo@uol.com.br https://orcid.org/0000-0002-9397-8678

Editor responsável pela aprovação do artigo: Dr. Ewerton Alex Avelar Editora responsável pela edição do artigo: Dra. Bruna Camargos Avelino 
ao modelo regulatório ( $\mathrm{R}^{2}$ de 58,96$)$, portanto não se rejeita a hipótese de pesquisa levantada de que as informações contábeis societárias são mais relevantes para os investidores em relação às informações contábeis regulatórias. Além disso, a análise adicional indicou que, ao segregar o período de investigação em 2011-2014 (período anterior à vigência da Orientação Técnica do Comitê de Pronunciamentos Contábeis (OCPC) 08) e em 2015-2018 (período posterior à vigência da OCPC 08), no anterior somente as informações contábeis regulatórias foram estatisticamente significativas e no posterior o modelo societário $\left(\mathrm{R}^{2}\right.$ de $\left.73,37 \%\right)$ denotou maior relevância em relação ao modelo regulatório ( $\mathrm{R}^{2}$ de $\left.65,41 \%\right)$. Essa maior relevância pode estar atrelada ao fato de que enquanto as demonstrações contábeis societárias têm como base os princípios, as demonstrações contábeis regulatórias do setor elétrico se fundamentam em regras fiscais e tarifárias específicas.

Palavras-Chave: Value Relevance. Contabilidade Societária. Contabilidade Regulatória. Setor Elétrico.

\title{
IFRS X REGULATORY GAAP: VALUE RELEVANCE OF BRAZILIAN ELECTRIC UTILITIES' ACCOUNTING INFORMATION
}

\begin{abstract}
In electric utility companies, financial statements must be presented according to International Financial Reporting Standards (IFRS) or Regulatory Generally Accepted Accounting Principles (GAAP). As such, we investigate which of the models best explains the share price variation of Brazilian electric companies from 2011 to 2018. Data were gathered from the Economaticaß database and the National Agency of Electric Energy (ANEEL) website. The analysis was performed using multiple regressions with panel data and model estimation based on the methodology of Collins, Maydew and Weiss (1997), developed from Ohlson (1995). Results showed that the IFRS model shows greater explanatory power ( $R^{2}$ of $65.39 \%$ ) in comparison to the regulatory GAAP model $\left(R^{2}\right.$ of 58.96), therefore our research hypothesis that corporate accounting information is more relevant to investors than regulatory accounting information was not rejected. Additionally, further analysis indicated that by segregating the investigation periods into 2011-2014 (prior to the Accounting Standards Committee Technical Orientation - OCPC 08) and 2015-2018 (after the issuance of OCPC 08), in the earlier only regulatory accounting information demonstrated statistical significance and in the later, corporate accounting information $\left(\mathrm{R}^{2}\right.$ of $73.37 \%$ ) revealed higher relevance than regulatory ( $R^{2}$ of $65.41 \%$ ). This higher relevance may be associated with the fact that IFRS financial statements are based on principles and regulatory financial statements of the power companies are based on tax and tariff sector-specific regulations.
\end{abstract}

Keywords: Value Relevance. IFRS. GAAP. Corporate Accounting. Regulatory Accounting. Electric Sector. 


\section{INTRODUÇÃO}

A contabilidade é de suma importância para os usuários por subsidiá-los na avaliação de empresas e na realização de investimentos. Mediante seus demonstrativos financeiros ou por meio dos índices e das variáveis contábeis, a contabilidade é capaz de gerar informações relevantes para a tomada de decisão e, de acordo com Corrêa, Neto, Nakao e Osajima (2012), este é um fator motivador do interesse de pesquisadores pela literatura de value relevance. Contudo, apesar de a informação contábil ser um dos principais meios de comunicação entre empresa e investidor externo (Guia \& Dantas, 2020), estudos recentes ainda questionam a relevância dessas informações para o mercado acionário (Barth, Li \& McClure, 2019; Santos, Lemes \& Barboza, 2019b).

Barth et al. (2019) analisaram a evolução da value relevance das informações contábeis das empresas listadas nas bolsas norte-americanas New York Stock Exchange (NYSE), National Association of Securities Dealers Automated Quotations (NASDAQ) e American Stock Exchange (AMEX) no período de 1962 a 2014 e encontraram, em conjunto, uma relação mais sútil, porém não em declínio, entre o preço das ações e as informações contábeis. Já Santos et al. (2019) realizaram uma meta-análise dos estudos publicados sobre a value relevance do lucro líquido e do patrimônio líquido das empresas brasileiras no período de 1997 a 2014 e os resultados indicam perda da relevância para o patrimônio líquido e ganho para o lucro líquido após a adoção das IFRS.

Inserida neste contexto, a presente pesquisa explora evidências sobre este assunto, concentrando-se em um setor específico, o setor brasileiro de energia elétrica que, como resultado da Resolução Normativa $n^{\circ}$. 396/2010 instituída pela ANEEL, deve apresentar além das demonstrações contábeis com base na Contabilidade Societária, as demonstrações contábeis em conformidade com a Contabilidade Regulatória de tal setor. Assim, ao considerar que diferentes valores podem ser reconhecidos nos grupos de contas contábeis, questiona-se: Qual modelo contábil, societário ou regulatório, é mais relevante para a formação do preço das ações das companhias brasileiras do setor de energia elétrica? Nesse sentido, o objetivo deste estudo consiste em verificar entre o modelo contábil societário e regulatório qual melhor explica a variação do preço das ações das companhias energéticas no Brasil.

Diferentes razões motivam esta pesquisa. O setor de energia elétrica é responsável pelo abastecimento de energia, fonte primordial para o funcionamento de praticamente todas as atividades de um país. Conforme Pereira, Santana, Mendes e Khan (2008), a energia elétrica é um componente da rede de infraestrutura que oferece suporte em âmbito social e econômico, por isso a manutenção e o desenvolvimento da sociedade e da economia brasileira são dependentes do seu provimento. Além do mais, a energia é um fator que impulsiona o Índice de Desenvolvimento Humano (IDH), conhecido como um parâmetro de bem-estar da população.

Outra razão é que o setor elétrico brasileiro passou por uma reestruturação desde a década de 1990, tanto em termos de infraestrutura como em termos legais, a qual resultou na Resolução Normativa n. 396 de 23 de fevereiro de 2010 instituída pela ANEEL, que tem como finalidade implantar 
as demonstrações contábeis regulatórias e estabelecer práticas e orientações para as empresas de energia elétrica. Então, visto que estas empresas são obrigadas a cumprir requisitos e apresentar suas demonstrações contábeis de forma societária, com base nas normas internacionais de contabilidade, e regulatória, fundamentada em regras fiscais e tarifárias específicas, divergências ocorrem na conciliação de alguns grupos de contas contábeis, o que, por sua vez, pode intrigar parte dos investidores (Guia \& Dantas, 2020), principalmente no tocante à relevância do lucro e do valor patrimonial contábil, e, consequentemente, afetar $\circ$ preço das ações negociadas no mercado acionário.

Hoppe (2012) analisa a diferença das práticas contábeis entre essas duas contabilidades e encontra distinções de aplicação ou falta dela nas práticas contábeis regulatórias. Nessa linha, os resultados do trabalho de Carvalho, Wanderley, Libonati e Santos (2014) apontam que há divergências entre as duas contabilidades quanto às contas de ativo total, resultado da atividade da concessão, receita líquida, lucro operacional e lucro líquido. Já o estudo de Suzart, Souza, Carvalho, Rivas e Martins (2012) examina se há diferenças significativas e qual a intensidade dessas entre os dados contábeis societários e regulatórios das empresas brasileiras do setor elétrico em referência ao Retorno sobre o Patrimônio Líquido (ROE) e ao Retorno sobre os Ativos (ROA), e os resultados indicam que, em média, o lucro regulatório é inferior, o patrimônio líquido e o ativo total são estatisticamente iguais e as informações societárias alteram os retornos de maneira mais intensa que as regulatórias.

Uma terceira razão são as diferenças entre os resultados dos estudos de value relevance em empresas do setor elétrico. Flores e Lopes (2019) avaliaram se no período pós IFRS (2010 - 2016) houve diminuições estatisticamente significativas na relevância das informações contábeis do setor elétrico brasileiro em relação ao período pré IFRS (2002 - 2009) e constataram que a adoção às normas internacionais resultou na redução da relevância, distanciando o valor do patrimônio contábil do valor de mercado das empresas de energia. Por outro lado, Ferreira, Carmo e Ribeiro (2020) verificaram a relevância do ativo financeiro das companhias elétricas brasileiras para o mercado de capitais entre 2010 e 2018 e encontraram que além do ativo financeiro registrado no contrato de concessão, o lucro líquido e o patrimônio líquido são informações relevantes para os investidores, e que o ativo financeiro, fruto das alterações advindas da adoção às IFRS, aumenta o poder de explicação do comportamento do preço das ações.

Essas diferenças podem estar atreladas à especificidade contábil do próprio setor, pois, nos últimos anos, as demonstrações contábeis societárias do setor elétrico sofreram alterações substanciais. Após a convergência internacional das normas contábeis, os ativos e passivos regulatórios que resultam da forma como a tarifação das atividades ocorre são retirados das demonstrações societárias das empresas elétricas e, segundo Flores e Lopes (2019), a redução da relevância da informação contábil encontrada para as companhias elétricas pós IFRS provavelmente tem ligação com a baixa desses itens regulatórios. Também houve mudanças na forma de contabilizar os contratos de concessão e as receitas. Com a emissão da Interpretação Técnica ICPC 01, fundamentada na IFRIC 12, o ativo imobilizado é desmembrado em ativo financeiro e/ou ativo intangível, dado que o concessionário não possui o 
direito de controlar o uso da infraestrutura de serviço público, mas sim o acesso para operar em nome do concedente, e a receita (contrapartida do ativo financeiro e/ou ativo intangível) é contabilizada conforme o Pronunciamento Técnico CPC 17 - Contratos de Construção, se resultar de construção ou melhoria, ou então segundo o Pronunciamento Técnico CPC 30 - Receitas, se resultar dos serviços de operação (Ferreira et al., 2020).

Frente a esse cenário, esta pesquisa verifica, de modo empírico, a relevância das informações contábeis publicadas nos demonstrativos tanto societários quanto regulatórios para os investidores no contexto do setor elétrico entre 2011 e 2018. Como análise adicional, o presente estudo segrega o período de investigação em período anterior à vigência da OCPC 08, de 2011 a 2014, e período posterior à vigência desta orientação técnica, de 2015 a 2018. Essa segregação acontece porque os ativos e passivos regulatórios, até então retirados das demonstrações societárias das empresas elétricas, voltaram a ser registrados novamente a partir de $1^{\circ}$ de janeiro de $2015 \mathrm{com}$ a vigência da OCPC 08 (2014), que trata do reconhecimento de determinados ativos e passivos nos relatórios contábil-financeiros das empresas de energia elétrica. Assim, pretende-se, por meio desta análise adicional, verificar e comparar o impacto da OCPC 08, que reestabelece o registro de tais ativos e passivos regulatórios, na relevância das informações contábeis societárias e regulatórias para o mercado de ações.

A contribuição deste estudo está em subsidiar órgãos normatizadores e reguladores sobre a implementação das normas contábeis, oferecer uma melhor compreensão das consequências oriundas das diferenças de tratamento contábil no setor elétrico e fornecer insights que podem comprovar a necessidade de aprimoramento das regras contábeis. Além disso, a pesquisa amplia o conhecimento dos pesquisadores e investidores ao comparar a relevância das informações reportadas nas demonstrações contábeis societárias e regulatórias do setor elétrico brasileiro, segregando o período em pré e pós vigência da OCPC 08.

Ademais, o Brasil é um país de análise interessante. Por ser emergente e caracterizado por baixa proteção legal aos acionistas minoritários e alta concentração acionária (La Porta, Lopez-de-Silanes, Shleifer \& Vishny, 2000; Ermel \& Do Monte, 2018; Loch, Silva, Bueno \& Marcon, 2020), tende a exibir um comportamento desigual frente a outros países considerados como mais desenvolvidos. Geralmente, em países em desenvolvimento, a demanda por importação de bens de capital é maior, as linhas de crédito de longo prazo são mais escassas e a captação de recursos é mais cara. Também porque o setor elétrico brasileiro conta com a participação direta do governo como acionista majoritário, o que pode culminar em potenciais conflitos e incertezas para os investidores (Loch et al., 2020). Outro motivo é que a adoção às normas internacionais de contabilidade pelos países ocorre em períodos distintos, em alguns de forma precoce e mais rápida e em outros de modo tardio e lentamente. 


\section{REFERENCIAL TEÓRICO}

\subsection{Aspectos Teóricos e Normativos sobre a Contabilidade Societária e Regulatória do Setor de Energia Elétrica}

No Brasil, a principal fonte de energia elétrica provém das hidrelétricas, logo este setor está interligado pelos segmentos de geração, transmissão, distribuição e comercialização de energia elétrica. Um fator relevante é que parte das companhias tem usufruto de concessões e permissões do poder público para prestar seus serviços à população, as quais são conhecidas como concessionárias e permissionárias do setor elétrico.

No que tange às normas de contabilidade aplicadas ao setor de energia elétrica, nos últimos anos houve mudanças normativas e regulatórias que impactaram, especialmente, as práticas contábeis. Neste sentido, o estudo realizado por Carvalho et al. (2014) aponta que os principais fatores que influenciaram o sistema contábil das empresas elétricas foram a convergência às normas internacionais de contabilidade, conhecidas como IFRS, que abrangeram as companhias de capital aberto, e a implementação da Contabilidade Regulatória.

As IFRS representam um conjunto de normas contábeis preparado sob a coordenação do International Accounting Standards Board - IASB, aceito por 166 jurisdições, incluído o Brasil, e que busca estabelecer um padrão contábil transparente, responsável e eficiente para o mercado financeiro mundial sobre aspectos de elaboração e divulgação das demonstrações financeiras (IFRS, 2018). Já a implementação da Contabilidade Regulatória do setor elétrico no Brasil é instituída pela ANEEL, por meio da Resolução Normativa $n^{\circ}$. 396/2010, e tem como apoio o Manual de Contabilidade do Setor Elétrico (MCSE), que estabelece práticas e orientações contábeis necessárias às concessionárias e permissionárias de serviço público de transmissão e de distribuição de energia elétrica para o registro contábil de suas respectivas operações e elaboração de demonstrações contábeis (ANEEL, 2013).

Segundo a OCPC 08 (2014), a tarifa de energia elétrica é formada pelos custos gerenciáveis e não gerenciáveis. Os custos gerenciáveis decorrem dos investimentos em infraestrutura e os não gerenciáveis representam os custos de aquisição da energia, portanto contemplam os itens regulatórios. Quando os custos de consumo incorridos são maiores (menores) do que os estimados, temse um direito a receber (uma obrigação a pagar), ou seja, um ativo (passivo) regulatório. Entretanto, com a adoção das normas contábeis internacionais em 2010, esse ativo (passivo) regulatório deixa de ser contabilizado nas demonstrações societárias das distribuidoras de energia, uma vez que: a) a entrega da energia é um evento futuro não controlado totalmente pela entidade; e b) quando surge esse direito (essa obrigação), não é praticável saber se e quais os compradores pagariam (receberiam) por esse direito (essa obrigação) (OCPC 08, 2014).

Então, em virtude do impedimento de contabilização dos itens regulatórios com a adoção das IFRS em 2010 e da consequente implementação da Contabilidade Regulatória por meio da Resolução Normativa n. 396 também em 2010, a partir de 2010 as informações contábeis do setor elétrico passaram a ser reportadas pela Contabilidade Societária e pela Contabilidade 
Regulatória. Nesse sentido, ao considerar que a regulação busca corrigir potenciais falhas, já que, de acordo com a Resolução Normativa $n^{\circ}$. 396, a contabilização dos ativos e passivos regulatórios aproxima as demonstrações contábeis dos eventos econômicos, pesquisas acerca das mudanças decorrentes da convergência e da obrigatoriedade da Contabilidade Regulatória são importantes. A Figura 1 demonstra algumas diferenças na contabilização das operações pela Contabilidade Societária e Regulatória antes da vigência da OCPC 08.

\begin{tabular}{|c|c|c|}
\hline Característica & Contabilidade Societária & Contabilidade Regulatória \\
\hline Ativos e passivos regulatórios & $\begin{array}{l}\text { Não houve correspondência } \\
\text { nas IFRS sobre o tratamento } \\
\text { de ativos e passivos } \\
\text { regulatórios. }\end{array}$ & $\begin{array}{lr}\text { Permanecem registrados } \\
\text { apenas ras } \\
\text { demonstrações } & \text { contábeis } \\
\text { regulatórias. } & \\
\end{array}$ \\
\hline Ativo imobilizado & $\begin{array}{l}\text { Adoção da ICPC } 01 \\
\text { Contratos de } \\
\text { pela Concessão } \\
\text { Societária, em que o ativo } \\
\text { imobilizado é segregado em } \\
\text { ativo intangível e/ou } \\
\text { financeiro. }\end{array}$ & $\begin{array}{l}\text { Segue o MCSE, em que os } \\
\text { ativos não devem ser } \\
\text { afetados pela ICPC } 01 \text { e } \\
\text { devem ser registrados } \\
\text { pelo valor homologado } \\
\text { pela ANEEL. }\end{array}$ \\
\hline $\begin{array}{l}\text { Conta de ativo imobilizado em } \\
\text { curso (utilizada para registrar } \\
\text { gastos em cursor com } \\
\text { construção, ampliação e/ou } \\
\text { melhoria) }\end{array}$ & $\begin{array}{l}\text { É criada uma ronta } \\
\text { retificadora para } \\
\text { transferência desses saldos } \\
\text { para a conta "custos de } \\
\text { construção", conforme IFRIC } \\
\text { 12, e para a conta de ativo } \\
\text { financeiro e intangível. }\end{array}$ & $\begin{array}{l}\text { Mantido pelo MCSE para } \\
\text { fins de regulação. }\end{array}$ \\
\hline $\begin{array}{l}\text { Conta de ativo imobilizado em } \\
\text { serviço (utilizada para registrar } \\
\text { gastos findos com construção, } \\
\text { ampliação e/ou melhoria) }\end{array}$ & $\begin{array}{l}\text { Essa conta é extinta, com a } \\
\text { transferência de seus saldos } \\
\text { para as contas de ativo } \\
\text { financeiro e intangível. }\end{array}$ & $\begin{array}{l}\text { Mantido pelo MCSE para } \\
\text { fins de regulação. }\end{array}$ \\
\hline $\begin{array}{l}\text { Custos e despesas operacionais } \\
\text { regulatórios }\end{array}$ & $\begin{array}{llrr}\text { Os custos } & \text { e } & \text { despesas } \\
\text { operacionais } & \text { não } & \text { são } \\
\text { diferenciados } & & \text { em } \\
\text { regulatórios } & \text { e } & \text { não } \\
\text { regulatórios, pois } & \text { não houve } \\
\text { correspondência } & \text { nas } & \text { IFRS } \\
\text { sobre o tratamento de custos } \\
\text { e despesas } & \text { operacionais } \\
\text { regulatórios. } & & \end{array}$ & $\begin{array}{l}\text { Insumo para análise da } \\
\text { formação tarifária pela } \\
\text { Superintendência de } \\
\text { Regulação Econômica da } \\
\text { ANEEL. Incluem: gastos } \\
\text { com pessoal, } \\
\text { administradores, material, } \\
\text { serviços de terceiros, } \\
\text { arrendamentos e aluguéis, } \\
\text { seguros, tributos e outros. }\end{array}$ \\
\hline Conta de receita de construção & $\begin{array}{l}\text { Criada apenas para fins } \\
\text { societários. Corresponde aos } \\
\text { valores justos } \\
\text { construções. }\end{array}$ & $\begin{array}{l}\text { Não existe no MCSE, } \\
\text { portanto não compõe os } \\
\text { demonstrativos } \\
\text { elaborados com base } \\
\text { nele. }\end{array}$ \\
\hline Conta de receita financeira & $\begin{array}{l}\text { Criada para a atualização } \\
\text { do ativo } \text { financeiro } \\
\text { indenizável, ou seja, do } \\
\text { valor residual do ativo } \\
\text { financeiro, representante do } \\
\text { valor da indenização a } \\
\text { receber do concedente. }\end{array}$ & $\begin{array}{l}\text { Não existe no MCSE, } \\
\text { portanto não compõe os } \\
\text { demonstrativos } \\
\text { elaborados com base } \\
\text { nele. }\end{array}$ \\
\hline
\end{tabular}




\begin{tabular}{|c|c|c|}
\hline Característica & Contabilidade Societária & Contabilidade Regulatória \\
\hline Conta de outros créditos & $\begin{array}{l}\text { Conta do ativo circulante } \\
\text { como contrapartida do fluxo } \\
\text { de caixa } \\
\text { recebido pela indenização } \\
\text { do raldo } \\
\text { residual do ativo financeiro. }\end{array}$ & $\begin{array}{l}\text { Não existe no MCSE, } \\
\text { portanto não compõe os } \\
\text { demonstrativos } \\
\text { elaborados com base } \\
\text { nele. }\end{array}$ \\
\hline
\end{tabular}

Figura 1 - Características divergentes entre a Contabilidade Societária e Regulatória

Fonte: Elaborada a partir do Manual de Orientação dos Trabalhos de Auditoria das Demonstrações Contábeis Regulatórias e adaptada de Brugni, Rodrigues, Cruz e Szuster (2012).

No entanto, em novembro de 2014, o Comitê de Pronunciamentos Contábeis (CPC) emite a OCPC 08, que trata do reconhecimento de determinados ativos e passivos nos relatórios contábil-financeiros das distribuidoras de energia elétrica. Por consequência, a partir de $1^{\circ}$ de janeiro de 2015 a Contabilidade Societária passa a reconhecer, novamente, ativos e passivos regulatórios até então contabilizados apenas pela Contabilidade Regulatória e tal fato ocorre porque a ANEEL passa a considerar o concedente (órgão público) como contrapartida dos ativos e/ou passivos financeiros oriundos das divergências tarifárias. Em decorrência disso, como análise adicional, a atual pesquisa também verifica a value relevance das informações contábeis societárias e regulatórias para o mercado acionário segregando o período em 2011 a 2014 (período anterior à vigência da OCPC 08) e em 2015 a 2018 (período posterior à vigência da OCPC 08).

\subsection{Value Relevance das Informações Contábeis}

De acordo com Lopes, Sant'Anna e Costa (2007), por volta da segunda metade do século XX, houve, nos estudos de contabilidade, notório crescimento das pesquisas de cunho positivista. Tais pesquisas foram desenvolvidas com base em trabalhos empíricos que evidenciavam o coeficiente de determinação, $R^{2}$ da regressão, para medir a relevância das informações contábeis.

Neste contexto, a partir da década de 1960, surgem os primeiros estudos sobre Value Relevance, relacionados às pesquisas de Ball e Brown (1968) e Beaver (1968), considerados precursores do tema na literatura contábilfinanceira. Seus trabalhos investigaram a relação entre os preços das ações e as informações divulgadas nas demonstrações contábeis e apontaram que o valor do patrimônio e do lucro contábil contém um poder informativo associado ao preço das ações.

Guia e Dantas (2020) afirmam que um dos principais objetivos da contabilidade é a relevância informacional contida nas demonstrações financeiras. Sob a ótica de Sami e Zhou (2004), a value relevance, ou relevância da informação contábil, corresponde à capacidade de os números contábeis representarem a informação contida no preço das ações. De maneira genérica, para Lopes e ludícibus (2012), esses estudos objetivam averiguar diversos aspectos referentes ao conteúdo informacional das demonstrações contábeis para o mercado de capitais. Tais estudos se baseiam nos preceitos difundidos por Malkiel e Fama (1970) sobre a Hipótese de Mercados Eficientes (Efficient Markets Hypotesis - EMH), em que os preços das ações podem refletir as informações relevantes e disponíveis e podem, também, ser ajustados em 
face desse conjunto de informações. Sendo assim, nota-se que o propósito desses estudos é capturar como o mercado de capitais reage às informações apresentadas nas demonstrações contábeis.

Em termos operacionais, Barth, Beaver e Landsman (2001) destacam que a finalidade das pesquisas de value relevance é verificar se a informação contábil é relevante para o mercado de capitais, dado certo nível de significância. Neste sentido, para ser relevante a informação contábil deve apresentar coeficientes de determinação e da equação de regressão significativamente diferentes de zero. Ainda em termos operacionais, Brown, Lo e Lys (1999) e Santos e Silva (2014) ressaltam que os trabalhos sobre a relevância da informação contábil são comumente realizados por meio de regressão, em que a variável dependente é o preço das ações e as variáveis independentes são o lucro e o patrimônio líquido por ação.

\subsubsection{Modelo Residual Income Valuation (RIV)}

As pesquisas empíricas sobre value relevance têm suas raízes associadas aos Modelos de Avaliação Patrimonial e, dentre tais, destaca-se o modelo Residual Income Valuation (RIV) de Ohlson (1995). A concepção de Lopes et al. (2007) sobre o modelo RIV demonstra que os resultados anormais (residual income) são os resultados líquidos (ou residuais) que uma companhia possui depois de retirar de seus resultados a parte que seria devida pela aplicação de seu capital a uma determinada taxa de remuneração mínima. O diferencial deste modelo consiste em calcular os resultados anormais a partir da taxa de juros livre de risco, ao invés de se basear no custo de capital da empresa para se chegar aos resultados anormais auferidos no período. Assim, conforme o RIV, os lucros (e não os dividendos) são a base de cálculo para o valor da empresa, que representa o somatório do valor presente dos lucros residuais futuros com o valor contábil do patrimônio líquido.

Santos e Silva (2014) destacam que, geralmente, os trabalhos de value relevance têm como base o modelo de Collins et al. (1997), desenvolvido a partir de Ohlson (1995). Apesar das críticas em relação ao coeficiente do lucro como medida de qualidade da informação (Dechow, Ge \& Schrand, 2010) e à ausência de variáveis de controle (Barth et al., 2019), este modelo (Equação (1)) é aplicado em diversas pesquisas de value relevance (Brown et al., 1999; Francis \& Schipper, 1999; Rezende, 2005; Gonçalves, Conegliam \& Carmo, 2017; Ferreira et al., 2020), inclusive nesta, por ter a vantagem de utilizar somente duas variáveis contábeis - lucro líquido e patrimônio líquido - para o cálculo do valor da empresa, por relacionar as informações contábeis com a avaliação do valor de mercado e, também, por permitir a análise do conteúdo informacional por meio da comparação entre os coeficientes de determinação $R^{2}$ dos modelos.

$$
P_{i, t}=a_{0}+\beta_{1} E_{i, t}+\beta_{2} B V_{i, t}+\varepsilon_{i, t}
$$

(Equação 1)

Em que:

$P_{i t}=$ preço da ação da empresa i quatro meses após o final do exercício social $t ;$

$E_{i j}=$ lucro líquido por ação da empresa $i$ no final do exercício social $t$;

$B V_{i j}=$ patrimônio líquido por ação da empresa $i$ no final do exercício social $t$;

$\varepsilon_{i}=$ termo de erro da regressão. 


\subsubsection{Estudos sobre Value Relevance no Brasil}

Diversas pesquisas sobre value relevance vêm sendo desenvolvidas no Brasil. Os estudos costumam destacar um diferencial contábil para, então, investigar possíveis alterações na relevância das informações contábeis, como por exemplo: a pesquisa e desenvolvimento (P\&D) (Hungarato \& Lopes, 2008); a substituição da Demonstração das Origens e Aplicações de Recursos pela Demonstração dos Fluxos de Caixa (Macedo, Machado, Murcia \& Machado, 2011); as operações de leasing operacional (Martins, Machado \& Machado, 2013); a adoção do fair value para mensuração de ativos biológicos (Martins, Machado \& Callado, 2014); a convergência às normas internacionais de contabilidade no Brasil (Gonçalves, Batista, Macedo \& Marques, 2014), a evidenciação de provisões e passivos contingentes (Pinto, Avelar, Fonseca, Silva \& Costa, 2014), a Demonstração do Resultado Abrangente (Angotti, Macêdo \& Bispo, 2016); o ativo intangível (Cappellesso, Rocha \& Dantas, 2018) e a Demonstração do Valor Adicionado (Santos, Botinha \& Lemes, 2019a).

No entanto, ainda há uma lacuna em relação ao tema, uma vez que estudos anteriores não verificaram e nem compararam a relevância das informações contábeis societárias e regulatórias do setor de energia elétrica para o mercado acionário. Dessa forma, ao considerar que as demonstrações contábeis societárias têm como base os princípios, ao passo que as demonstrações contábeis regulatórias do setor elétrico se fundamentam em regras fiscais e tarifárias específicas, elabora-se a seguinte hipótese de pesquisa:

$H_{1}$ : As informações contábeis coletadas a partir de demonstrações societárias são mais relevantes para os investidores em relação às informações contábeis coletadas a partir de demonstrações regulatórias.

Conforme Loch et al. (2020) as empresas do setor de energia elétrica contam com a participação direta do governo como acionista majoritário, o que pode resultar em potenciais conflitos e incertezas para os investidores, pois, segundo Peltzman (1976), as agências reguladoras objetivam beneficiar grupos de interesses distintos, ao invés de um único agente econômico. Sendo assim, acredita-se que a contabilidade e a estrutura regulatória podem oferecer vantagens a determinados grupos, o que pode dificultar 0 andamento ordenado da atividade econômica. Com base nisso e pelo fato de que as demonstrações societárias têm como base os princípios contábeis e a essência sobre a forma, acredita-se que as informações contábeis societárias são mais relevantes para o mercado acionário.

\section{PROCEDIMENTOS METODOLÓGICOS}

Esta pesquisa analisou as empresas brasileiras do setor de energia elétrica que negociaram ações na B3 - Brasil, Bolsa, Balcão no período de 2011 a 2018. A janela temporal teve início em 2011 por ser o ano em que a Resolução Normativa ANEEL $n^{\circ} 396$ (2010) entra em vigor, então as demonstrações contábeis regulatórias passam a ser de divulgação obrigatória.

O preço da ação, as informações contábeis societárias (lucro líquido e patrimônio líquido por ação), a quantidade de ações e o Cadastro Nacional da Pessoa Jurídica (CNPJ) de cada empresa foram retirados da base de dados da Economatica®. Já as informações contábeis regulatórias (lucro líquido e 214 Revista Contabilidade Vista \& Revista, ISSN 0103-734X, Universidade Federal de Minas Gerais, Belo Horizonte, v. 32, n. 2, p. 205-229, maio/ago. 2021 
patrimônio líquido) foram obtidas no sítio eletrônico da ANEEL (http://www.aneel.gov.br/central-de-informacoes-economico-financeiras), o qual fornece a opção de busca das demonstrações financeiras regulatórias por meio do CNPJ individual da empresa.

A amostra inicial foi composta por 40 empresas, ao considerar somente a classe de maior volume de negociação no momento da coleta de dados (fevereiro/2020). Entretanto, como 21 empresas não divulgaram em nenhum ano o Balanço Patrimonial Regulatório e a Demonstração do Resultado Regulatória, a amostra final corresponde a 19 empresas. Optou-se por manter a mesma quantidade de observações societárias e regulatórias por variável.

Os dados coletados foram organizados em painéis curtos e analisados por meio de regressões múltiplas, estimadas pelo método dos Mínimos Quadrados Ordinários (MQO). De acordo com Baltagi (2009), a técnica de dados em painel ou de dados longitudinais consiste em um conjunto de dados combinados em dimensões tanto de série temporal como de corte transversal. Os painéis de dados permitem explorar, simultaneamente, variações das variáveis ao longo do tempo e entre diferentes unidades ou grupos.

O estudo foi dividido em três etapas. A primeira etapa representou a análise da value relevance das informações contábeis societárias e regulatórias para o mercado acionário no período de 2011 a 2018. Na segunda etapa, verificou-se a value relevance das informações contábeis societárias e regulatórias para os acionistas entre 2011 e 2014, período anterior à vigência da OCPC 08. Na última etapa identificou-se a value relevance das informações contábeis societárias e regulatórias para o mercado acionário entre 2015 e 2018, período posterior à vigência da OCPC 08. Como nas três etapas as informações contábeis societárias foram comparadas com as regulatórias, seis modelos empíricos foram elaborados com base na metodologia de Collins et al. (1997):

$$
\begin{aligned}
& P_{i, t}=a_{0 \dagger}+\beta_{1+} L L P A \_S O C_{i, t}+\beta_{2+} P L P A \_S O C_{i, t}+\varepsilon_{i, t} \\
& P_{i, t}=a_{0 \dagger}+\beta_{1+} L L P A \_R E G_{i, t}+\beta_{2 t} P L P A \_R E G_{i, t}+\varepsilon_{i, t}
\end{aligned}
$$

Em que:

$P_{\text {it }}$ é o preço da ação da empresa i quatro meses após o final do exercício social $t ;$

LLPA_SOC it é o lucro líquido por ação societário da empresa i no final do exercício social t;

LLPA_REG it é o lucro líquido por ação regulatório da empresa i no final do exercício social t;

PLPA_SOC it é o patrimônio líquido por ação societário da empresa i no final do exercício social t;

PLPA_REG it é o patrimônio líquido por ação regulatório da empresa i no final do exercício social $t$;

As equações (2) e (3) correspondem ao período de 2011 a 2018; de 2011 a 2014 e de 2015 a 2018. O preço da ação é a variável dependente e o lucro e patrimônio líquido por ação são as variáveis independentes. 
Vale ressaltar que os pares de painéis possuem o mesmo parâmetro, ou seja, a mesma amostra de empresas e o mesmo intervalo de tempo, tanto para os dados contábeis societários quanto para os dados contábeis regulatórios.

O preço da ação utilizado foi o preço de fechamento na data de 30 de abril do ano seguinte ao da publicação das demonstrações (Gonçalves et al., 2017; Ferreira et al., 2020) (com tolerância de uma semana após esta data) e retirou-se do patrimônio líquido o lucro líquido, por este já compor a conta de patrimônio líquido no balanço patrimonial.

Com o propósito de atender aos pressupostos da regressão, os testes Jarque-Bera e Breusch-Pagan-Godfrey foram realizados para verificar a normalidade e a homocedasticidade dos resíduos, respectivamente. Para identificar se existem problemas de multicolinearidade e de especificação dos modelos, calculou-se o FIV (Variance Inflation Fator) e os testes linktest e RESET (Regression Specification Error Test) (Fávero \& Belfiore, 2017). Já para definir o modelo de dados em painel mais apropriado para esta pesquisa, se POLS, de Efeitos Fixos ou de Efeitos Aleatórios, os testes $F$ de Chow, Lagrangian Multiplier de Breusch-Pagan e Hausman foram feitos. Utilizou-se a técnica de Hadi (1994) para a exclusão dos outliers e o software Stata 13® para a análise dos dados.

\section{ANÁLISE E DISCUSSÃO DOS RESULTADOS}

A Tabela 1 apresenta as estatísticas descritivas do preço das ações e das variáveis contábeis (lucro líquido e patrimônio líquido por ação) societárias e regulatórias após a exclusão dos outliers para o período de 2011 a 2018.

\section{Tabela 1}

Estatísticas descritivas das variáveis societárias e regulatórias

\begin{tabular}{ccccc}
\hline Variáveis & Média & Desvio-padrão & Mínimo & Máximo \\
\hline P & 17,9044 & 12,3885 & 1,3126 & 53,2692 \\
LLPA_SOC & $-0,2882$ & 17,2589 & $-102,1972$ & 95,4247 \\
LLPA_REG & $-0,5427$ & 12,4400 & $-104,1202$ & 24,4407 \\
PLPA_SOC & 21,5434 & 55,3867 & $-140,8049$ & 247,4395 \\
PLPA_REG & 10,7856 & 40,8661 & $-147,9376$ & 210,0383 \\
\hline
\end{tabular}

Fonte: Dados da pesquisa.

Observa-se que, em média, os valores societários do lucro líquido e do patrimônio líquido por ação são superiores em comparação com os valores regulatórios. Em relação ao patrimônio líquido, as divergências encontradas entre os valores societários e regulatórios das empresas elétricas podem estar relacionadas ao não reconhecimento dos ativos e passivos regulatórios pela Contabilidade Societária no período anterior à emissão da OCPC 08, bem como pelas reavaliações de Ativos Imobilizados a Valor Novo de Reposição feitas pela Contabilidade Regulatória e pelos efeitos da adoção da ICPC 01 na Contabilidade Societária, que desmembra o ativo imobilizado em ativo financeiro e/ou ativo intangível.

No que tange às discrepâncias nos valores referentes ao lucro líquido, tais evidências são congruentes aos resultados do trabalho de Medeiros, Wanderley, 216 Revista Contabilidade Vista \& Revista, ISSN 0103-734X, Universidade Federal de Minas Gerais, Belo Horizonte, v. 32, n. 2, p. 205-229, maio/ago. 2021. 
Araújo e Santos (2013), o qual mostra que, em média, os valores societários dos lucros líquidos são superiores aos regulatórios. O desvio-padrão para os dados societários é maior e, assim como no estudo de Flores e Lopes (2019), o desviopadrão do patrimônio líquido societário é superior quando comparado ao desvio-padrão do lucro líquido societário. Enquanto os valores mínimos são próximos, os valores máximos são mais distantes.

Os resultados da etapa 1 são evidenciados na Tabela 2. Essa tabela é composta pelo Painel A - Resultados Societários, e pelo Painel B - Resultados Regulatórios.

\section{Tabela 2}

Resultado da Relevância do LLPA e PLPA para o período de 2011 a 2018

\begin{tabular}{|c|c|c|c|}
\hline \multicolumn{4}{|c|}{ Painel A - Societário } \\
\hline Variáveis & Coeficiente & $t$ & p-valor \\
\hline LLPA_SOC & $5,5017^{* * *}$ & 5,70 & 0,000 \\
\hline PLPA_SOC & $1,5664^{* * *}$ & 4,99 & 0,000 \\
\hline C & $-8,3207^{*}$ & $-2,33$ & 0,027 \\
\hline Informaçōes Adicionais & Valores & Informações Adicionais & Valores \\
\hline Jarque-Bera (p-valor) & 0,7736 & RESET (p-valor) & 0,4327 \\
\hline Breusch-Pagan (p-valor) & 0,1064 & F de Chow (p-valor) & 0,0000 \\
\hline VIF (LLPA_SOC) & 2,44 & LM Breusch-Pagan & 0,0004 \\
\hline VIF (PLPA_SOC) & 2,44 & Hausman & 0,0018 \\
\hline Linktest_hatsq (p-valor) & 0,455 & $\mathrm{R}^{2}$ Within & 0,6539 \\
\hline \multicolumn{4}{|c|}{ Painel B - Regulatório } \\
\hline Variáveis & Coeficiente & $t$ & p-valor \\
\hline LLPA_REG & $3,8794^{* *}$ & 2,72 & 0,007 \\
\hline PLPA_REG & $0,8982^{* *}$ & 3,05 & 0,002 \\
\hline C & 2,9701 & 0,88 & 0,381 \\
\hline Informações Adicionais & Valores & Informações Adicionais & Valores \\
\hline Jarque-Bera (p-valor) & 0,7638 & RESET (p-valor) & 0,1842 \\
\hline Breusch-Pagan (p-valor) & 0,1318 & F de Chow (p-valor) & 0,0000 \\
\hline VIF (LLPA_REG) & 2,27 & LM Breusch-Pagan & 0,0000 \\
\hline VIF (PLPA_REG) & 2,27 & Hausman & 0,0575 \\
\hline Linktest_hatsq (p-valor) & 0,227 & $\mathrm{R}^{2}$ Between & 0,5896 \\
\hline
\end{tabular}

Nota: ***Estatisticamente significativa ao nível de 0,01\% (p-valor <0,0001); **Estatisticamente significativa ao nível de $1 \%$ ( $p$-valor <0,01); *Estatisticamente significativa ao nível de 5\% (pvalor $<0,05)$.

Fonte: Dados da pesquisa.

Os testes Jarque-Bera e Breusch-Pagan indicam que os resíduos seguem distribuição normal e apresentam variância constante. O VIF menor que 4 mostra que as variáveis explicativas não possuem correlações perfeitas ou elevadas. O linktest não rejeita a hipótese nula de que os modelos são estimados corretamente em termos de forma funcional e o teste RESET aponta que não há omissão de variáveis explicativas relevantes. Os testes $F$ de Chow, Lagrangian Multiplier de Breusch-Pagan e de Hausman indicam que o modelo com efeito fixo (variação within predominante) é o mais adequado para os dados societários, enquanto o modelo com efeito aleatório (variação between 
predominante) é o mais apropriado para os dados regulatórios (Fávero \& Belfiore, 2017).

Percebe-se que todas as variáveis (LLPA_SOC, PLPA_SOC, LLPA_REG e PLPA_REG) são estatisticamente significativas ao nível de $0,01 \%$ ou $1 \%$, logo as informações contábeis societárias e regulatórias são relevantes para a formação do preço das ações das empresas do setor elétrico brasileiro no período entre 2011 e 2018. Outros estudos também confirmam a influência do lucro e do patrimônio líquido no preço das ações das empresas de capital aberto (Barth, Landsman \& Lang, 2008; Gonçalves et al., 2014; Cappellesso et al., 2018).

Barth et al. (2019) descobriram aumentos na relevância, sobretudo, dos valores relacionados aos ativos intangíveis, oportunidades de crescimento e medidas alternativas de desempenho. Segundo Moura, Fank e Varela (2012) a maior parte das empresas brasileiras de energia elétrica contabiliza os contratos de concessão na conta de ativo intangível e como esses contratos podem persistir por décadas, talvez impactem de modo substancial as decisões dos acionistas.

O Painel A mostra que, em média, $65,39 \%$ da variação do preço das ações é explicada pela variação do lucro e do patrimônio líquido societários. Por outro lado, o Painel B revela que, em média, essa variação é de $58,96 \%$. Quanto maior for o valor dessas variáveis, maior é o preço da ação, visto que as variáveis possuem coeficientes positivos. Ao comparar $0 \mathrm{R}^{2}$ (coeficiente de determinação) dos dois painéis, nota-se que $\circ R^{2}$ do Painel $A$ - Societário $(65,39 \%)$ é maior que o $R^{2}$ do Painel $B$ - Regulatório $(58,96 \%)$. O coeficiente de determinação $\left(R^{2}\right)$ é uma medida de ajustamento de um modelo estatístico e indica, em porcentagem, o quanto que o modelo consegue explicar dos valores observados. Quanto maior $O R^{2}$, mais explicativo é considerado $O$ modelo, ou seja, melhor ele se ajusta à amostra.

Além disso, observa-se que o nível de significância estatística das variáveis societárias $(0,01 \%)$ é maior do que das variáveis regulatórias (1\%). Essas evidências não rejeitam a hipótese de pesquisa levantada de que as informações contábeis coletadas a partir de demonstrações societárias são mais relevantes para os investidores em relação às informações contábeis coletadas a partir de demonstrações regulatórias, pois o poder explicativo da Equação (2) é superior ao da Equação (3).

Com a convergência internacional das normas contábeis em 2010, os ativos e passivos regulatórios são retirados das demonstrações societárias das empresas do setor elétrico. No entanto, a partir de $1^{\circ}$ de janeiro de 2015 entra em vigor a OCPC 08 (2014), portanto tais itens regulatórios voltam a ser registrados pelas empresas elétricas. Nesse sentido, como análise adicional, verifica-se a value relevance das informações contábeis societárias e regulatórias para os acionistas entre 2011 e 2014, período anterior à vigência da OCPC 08 (2014), assim como para os anos de 2015 a 2018, período posterior à vigência da OCPC 08 (2014). Os resultados são apresentados nas Tabelas 3 e 4. 
Tabela 3

Resultado da Relevância do LLPA e PLPA para o período de 2011 a 2014

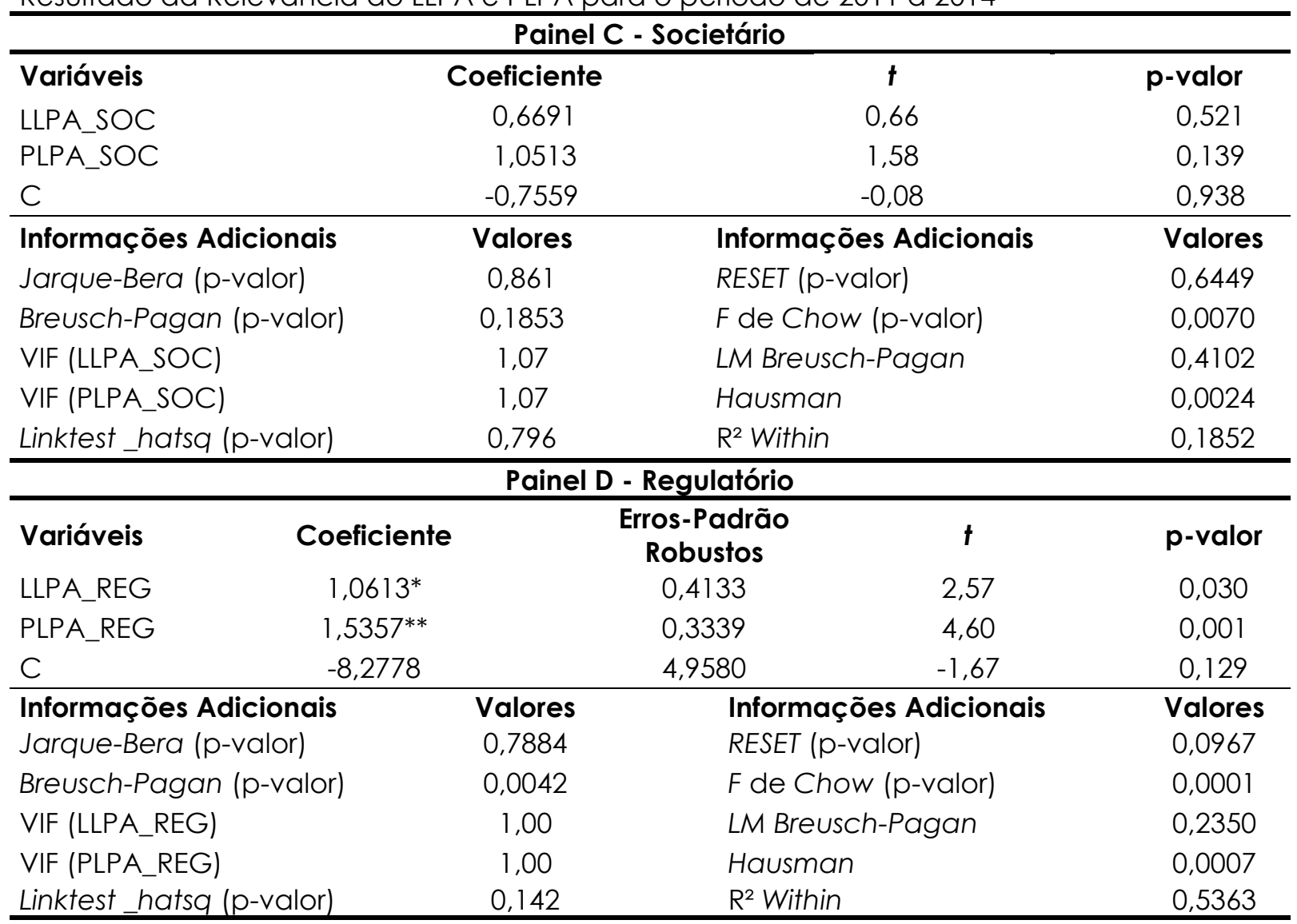

Nota: ${ }^{* * *}$ Estatisticamente significativa ao nível de $0,01 \%$ ( $p$-valor $<0,0001$ ); ${ }^{* *}$ Estatisticamente significativa ao nível de $1 \%$ ( $p$-valor $<0,01)$; *Estatisticamente significativa ao nível de $5 \%$ (pvalor $<0,05)$.

Fonte: Dados da pesquisa.

A Tabela 3 mostra que os resíduos seguem distribuição normal (p-valor do teste Jarque-Bera $>0,05)$, as variáveis explicativas não apresentam um elevado percentual de variância compartilhada (VIF < 4), os modelos são estimados corretamente em termos de forma funcional ( $p$-valor do _hatsq > 0,05), não há omissão de variáveis explicativas relevantes ( $\mathrm{p}$-valor do teste RESET $>0,05$ ) e os testes $F$ de Chow, Lagrangian Multiplier de Breusch-Pagan e de Hausman apontam que o modelo com efeito fixo (variação within predominante) é o mais indicado para os dados societários e regulatórios (Fávero \& Belfiore, 2017). Sobre o teste de heterocedasticidade de Breusch-Pagan, a variância dos resíduos é constante no modelo societário (Painel C) e não constante para o modelo regulatório (Painel $\mathrm{D}, \mathrm{p}$-valor $<0,05$ ). Em virtude disso, o modelo de regressão regulatório é estimado com erros-padrão robustos clusterizados por empresa, ou seja, com erros-padrão robustos com agrupamento por indivíduo (Fávero \& Belfiore, 2017).

Constata-se que entre 2011 e 2014, período que antecede à vigência da OCPC 08 (2014), somente as variáveis contábeis regulatórias são estatisticamente significativas ao nível de $1 \%$ ou 5\%, que o LLPA_REG e o PLPA_REG apresentam coeficientes positivos e que o poder de explicação do modelo é de 53,63\%. Essas evidências sugerem que quando a empresa divulga 
informações contábeis específicas do seu negócio para o mercado, as mesmas tornam as demonstrações financeiras mais relevantes. Nesse sentido, Braga, Carmo e Cunha (2021) analisaram se tem diferença na relevância da informação contábil, em relação ao valor de mercado, entre as empresas do segmento de construção civil e incorporação imobiliária e as empresas dos demais segmentos e encontraram que os métodos de reconhecimento de receitas específicos para o segmento de construção civil e incorporação imobiliária impactam a relevância da informação contábil. Já a falta de significância estatística para os dados societários pode decorrer do não reconhecimento dos ativos e passivos regulatórios pela Contabilidade Societária das empresas do setor de energia elétrica no período que antecede à vigência da OCPC 08 (2014), visto que, segundo Flores e Lopes (2019), este não reconhecimento afeta negativamente tais empresas no Brasil.

\section{Tabela 4}

Resultado da Relevância do LLPA e PLPA para o período de 2015 a 2018

\begin{tabular}{|c|c|c|c|}
\hline \multicolumn{4}{|c|}{ Painel E - Societário } \\
\hline Variáveis & Coeficiente & $t$ & p-valor \\
\hline LLPA_SOC & $6,9299 * * *$ & 4,22 & 0,000 \\
\hline PLPA_SOC & 0,2289 & 0,71 & 0,477 \\
\hline C & 3,9301 & 1,18 & 0,237 \\
\hline Informações Adicionais & Valores & Informações Adicionais & Valores \\
\hline Jarque-Bera (p-valor) & 0,8946 & RESET (p-valor) & 0,7799 \\
\hline Breusch-Pagan (p-valor) & 0,3090 & F de Chow (p-valor) & 0,0013 \\
\hline VIF (LLPA_SOC) & 2,81 & LM Breusch-Pagan & 0,0023 \\
\hline VIF (PLPA_SOC) & 2,81 & Hausman & 0,0704 \\
\hline Linktest_hatsq ( $\mathrm{p}$-valor) & 0,963 & $\mathrm{R}^{2}$ Between & 0,7337 \\
\hline \multicolumn{4}{|c|}{ Painel F - Regulatório } \\
\hline Variáveis & Coeficiente & $t$ & p-valor \\
\hline LLPA_REG & $5,1818^{* *}$ & 2,60 & 0,009 \\
\hline PLPA_REG & 0,5175 & 1,48 & 0,138 \\
\hline $\mathrm{C}-$ & 5,9997 & 1,63 & 0,103 \\
\hline Informações Adicionais & Valores & Informações Adicionais & Valores \\
\hline Jarque-Bera (p-valor) & 0,7496 & RESET (p-valor) & 0,2292 \\
\hline Breusch-Pagan (p-valor) & 0,2681 & F de Chow (p-valor) & 0,0019 \\
\hline VIF (LLPA_REG) & 2,31 & LM Breusch-Pagan & 0,0000 \\
\hline VIF (PLPA_REG) & 2,31 & Hausman & 0,4459 \\
\hline Linktest_hatsq (p-valor) & 0,471 & $\mathrm{R}^{2}$ Between & 0,6541 \\
\hline
\end{tabular}

Nota: ${ }^{* * *}$ Estatisticamente significativa ao nível de $0,01 \%$ ( $p$-valor $<0,0001$ ); ${ }^{* *}$ Estatisticamente significativa ao nível de $1 \%$ ( $p$-valor <0,01); *Estatisticamente significativa ao nível de 5\% (pvalor $<0,05)$.

Fonte: Dados da pesquisa.

Em relação ao período de 2015 a 2018, em ambos os casos (societário e regulatório), a hipótese nula de distribuição normal e variância constante dos resíduos não é rejeitada. O VIF mostra que não há problemas de multicolinearidade nas variáveis explicativas, o linktest não rejeita a hipótese nula de especificação correta do modelo em termos de forma funcional e o 
teste RESET revela que não há omissão de variáveis explicativas relevantes. Os testes $F$ de Chow, Lagrangian Multiplier de Breusch-Pagan e de Hausman demonstram que o modelo com efeito aleatório (variação between predominante) é o mais indicado para os dados societários e regulatórios (Fávero \& Belfiore, 2017).

Verifica-se que apenas o lucro líquido por ação societário e regulatório é estatisticamente significativo ao nível de 0,01\% (LLPA_SOC) e 1\% (LLPA_REG). A relação encontrada entre as variáveis preço por ação e lucro líquido por ação é positiva para as duas contabilidades, logo, em média, um aumento de $\mathrm{R} \$ 1,00$ no lucro líquido por ação resulta no aumento de $R \$ 6,93$ (societária) ou de $R \$$ 5,18 (regulatória) no preço da ação. O Painel E revela que, em média, 73,37\% da variação do preço das ações é explicada pela variação do lucro líquido por ação societário. Já o Painel $F$ indica que, em média, essa variação é de $65,41 \%$ para os dados regulatórios. Macedo, Machado, Machado e Mendonça (2013), Gonçalves et al. (2014) e Santos et al. (2019b) encontraram que a variável lucro líquido por ação se tornou mais relevante do que a variável patrimônio líquido por ação após o processo de convergência internacional da contabilidade. Além disso, Santos et al. (2019a) pesquisaram se o conteúdo informacional da Demonstração do Valor Adicionado (DVA) é relevante para os investidores e os achados mostraram que o poder explicativo do lucro por ação é superior em comparação à DVA. Acredita-se que em países emergentes onde a proteção legal dos acionistas é menor, caso do Brasil (La Porta et al., 2000), a maior relevância do lucro pode ser justificada pelo fato de os lucros refletirem mais rapidamente a condição financeira das empresas em um ambiente de risco. Em contrapartida, Lima (2010) afirma que após a adoção das normas contábeis internacionais, o patrimônio contábil se aproxima do valor de mercado das empresas listadas na bolsa de valores, por isso a sua relevância também deveria ser confirmada.

Ao comparar os Painéis C (Societário - 2011 a 2014) e E (Societário - 2015 a 2018), observa-se que as variáveis lucro e patrimônio líquido não são significantes no Painel C, mas que o lucro líquido passa a ser ao nível de 0,01\% no Painel E. Isso mostra que, após a vigência da OCPC 08 (2014), o lucro líquido societário se torna relevante para os investidores das empresas do setor elétrico brasileiro. Este achado ressalta a importância da emissão da OCPC 08 que entrou em vigor a partir de $1^{\circ}$ de janeiro de 2015 e sugere que a flexibilização de procedimentos em setores específicos, como o setor elétrico, de tecnologia e de intenso uso de capital intelectual pode aumentar a relevância das informações contábeis. Ao comparar o $R^{2}$ dos Painéis D (Regulatório - 2011 a 2014) e $F$ (Regulatório - 2015 a 2018), nota-se que o $R^{2}$ do Painel $F(65,41 \%)$ é superior ao $R^{2}$ do Painel $D(53,63 \%)$. Isso significa que, após a vigência da OCPC 08 (2014), houve um ganho do poder de explicação do preço da ação das empresas do setor elétrico brasileiro por meio do lucro líquido regulatório.

Nesse sentido, a presente pesquisa vai ao encontro do estudo realizado por Carvalho et al. (2014), o qual aponta diferenças em dados contábeis específicos entre as duas contabilidades, societária e regulatória. As evidências também seguem o mesmo sentido do trabalho de Suzart et al. (2012) sobre a importância dessas duas contabilidades. Os autores mostram que o lucro regulatório é inferior ao lucro societário e que os dados societários são mais expressivos que os dados regulatórios ao explicar o ROE e o ROA, ou seja, 
alteram os retornos de maneira mais intensa. Os achados ainda corroboram o estudo de Santos et al. (2019b), o qual indica perda da relevância do patrimônio líquido e ganho da relevância do lucro líquido após a adoção das IFRS.

De modo geral, possíveis explicações para os resultados encontrados se devem aos diferentes critérios praticados pela Contabilidade Societária e Regulatória na contabilização dos ativos e passivos regulatórios no período que antecede a vigência da OCPC 08. Além disso, os ativos imobilizados a Valor Novo de Reposição podem ser reavaliados pela Contabilidade Regulatória e, após a emissão da ICPC 01 houve o desmembramento do ativo imobilizado em ativo financeiro e/ou ativo intangível, o que pode impactar o valor das tarifas cobradas pelas empresas do setor elétrico brasileiro.

Destaca-se ainda o fato de que a Contabilidade Societária tem como base as normas internacionais. Essas normas são submetidas às companhias de capital aberto, que por sua vez são fiscalizadas pela Comissão de Valores Mobiliários (CVM), portanto acredita-se que as demonstrações contábeis societárias correspondem melhor aos interesses dos investidores. Por outro lado, a Contabilidade Regulatória é regida pelo MCSE, então visa atender às demandas do órgão regulador específico, que no caso das companhias elétricas é a ANEEL.

\section{CONCLUSÕES}

Perante a obrigatoriedade da divulgação de demonstrações contábeis regulatórias pelas empresas do setor elétrico, conforme a Resolução Normativa $n^{\circ}$. 396/2010 instituída pela ANEEL, a Contabilidade Regulatória é mais uma das fontes de informação contábil, se fazendo presente no rol de dados disponíveis aos analistas do mercado acionário.

Inicialmente, este estudo verifica a relevância das informações contábeis reportadas pela Contabilidade Societária e pela Contabilidade Regulatória, ao identificar o poder explicativo de cada uma delas influenciar o preço das ações das empresas brasileiras de energia elétrica no período entre 2011 e 2018. Ou seja, esta pesquisa objetiva verificar, entre o modelo contábil societário e regulatório, qual melhor explica a variação do preço das ações das companhias energéticas no Brasil.

Os resultados apontam que as variáveis societárias (lucro líquido e patrimônio líquido por ação) apresentam poder explicativo superior ( $R^{2}$ de $65,39 \%$ ) em comparação com os valores das mesmas variáveis regulatórias ( $R^{2}$ de $58,96 \%)$. Dessa maneira, não se rejeita a hipótese de pesquisa levantada de que as informações contábeis coletadas a partir de demonstrações societárias são mais relevantes para os investidores em relação às informações contábeis coletadas a partir de demonstrações regulatórias.

Em seguida, como análise adicional, verifica-se a value relevance das informações contábeis societárias e regulatórias para os acionistas entre 2011 e 2014, período anterior à vigência da OCPC 08, e entre 2015 e 2018, período posterior à vigência da OCPC 08. No período pré OCPC 08 somente as variáveis contábeis regulatórias são estatisticamente significativas e no período pós OCPC 08 o patrimônio líquido regulatório não apresenta significância estatística, o 
lucro líquido societário se torna relevante e há um incremento do poder de explicação do preço da ação das empresas do setor elétrico brasileiro por meio da relevância do lucro líquido societário. Como o Brasil é um país emergente, caracterizado por baixa proteção legal aos acionistas minoritários, alta concentração acionária e linhas de crédito de longo prazo mais escassas (La Porta et al., 2000; Ermel \& Do Monte, 2018; Loch et al., 2020), acredita-se que a maior relevância do lucro pode ser justificada pelo fato de os lucros refletirem mais rapidamente a condição financeira das empresas em um ambiente de risco.

No geral, os resultados evidenciam que as informações contábeis (lucro líquido e patrimônio líquido por ação) são relevantes para o mercado brasileiro de capitais, quer sejam reportadas pela Contabilidade Societária, quer sejam apresentadas pela Contabilidade Regulatória, ressaltando que para os períodos de 2011 a 2018 e de 2015 a 2018, os dados societários possuem maior grau de relevância. Outros estudos também evidenciaram a influência do lucro e do patrimônio líquido por ação no preço das ações das empresas de capital aberto (Barth et al., 2008; Gonçalves et al., 2014; Cappellesso et al., 2018).

Assim, conclui-se que as informações contábeis societárias, fundamentadas em IFRS, são mais relevantes que as informações regulatórias e que os investidores reagem positivamente a essas informações nos dois casos. Essa maior relevância da Contabilidade Societária pode estar atrelada ao fato de as normas internacionais serem mais voltadas para o mercado de capitais, além de as informações societárias fornecerem números mais próximos da realidade econômica da empresa, posto que tal contabilidade reflete, de modo mais amplo, o fato econômico. Ademais, enquanto as demonstrações contábeis societárias são elaboradas a partir das normas internacionais de contabilidade, que têm como base os princípios e a essência sobre a forma, as demonstrações contábeis regulatórias, neste caso, do setor de energia elétrica, se fundamentam em regras fiscais e tarifárias específicas.

Apesar de o número de empresas analisadas ser próximo de outros trabalhos que também investigaram companhias de capital aberto do setor elétrico (Carvalho et al., 2014; Flores \& Lopes, 2019), a limitação principal deste estudo se concentra na indisponibilidade das demonstrações financeiras regulatórias, por parte de várias empresas listadas no site da ANEEL. Futuras pesquisas podem ser realizadas com o objetivo de averiguar se as normas regulatórias estão sendo aplicadas de acordo com o MCSE. Por fim, este estudo contribuiu com a crescente literatura que investiga as mudanças na relevância da informação contábil para o mercado de capitais no que tange ao setor de energia elétrica.

\section{REFERÊNCIAS}

Agência Nacional de Energia Elétrica - ANEEL. (2010). Resolução Normativa RN $n^{\circ}$. 396/2010. Recuperado de http://www.aneel.gov.br/cedoc/ren2010396.pdf. Acesso em fevereiro de 2020. 
Agência Nacional de Energia Elétrica - ANEEL. (2013). Manual de Contabilidade do Setor Elétrico - MCSE. Brasilia. Recuperado de http://www.aneel.gov.br/aplicacoes/audiencia/arquivo/2013/026/documen to/produto_5_-_final.pdf. Acesso em fevereiro de 2020.

Angotti, M., Macêdo, H. C., \& Bispo, O. N. A. (2016). Poder preditivo e value relevance da demonstração do resultado abrangente: uma análise das companhias brasileiras listadas na BM\&FBOVESPA. Enfoque: Reflexão Contábil, 35(3), 1-17. DOI: https://doi.org/10.4025/enfoque.v35i3.32635

Ball, R., \& Brown, P. (1968). An empirical evaluation of accounting income numbers. Journal of Accounting Research, 6(2), 159-178. DOl: https://doi.org/10.2307/2490232

Baltagi, B. H. (2009). Econometric analysis of panel data (5a ed.). New York: John Wiley \& Sons.

Barth, M. E., Beaver, W. H., \& Landsman, W. R. (2001). The relevance of the value relevance literature for financial accounting standard setting: another view. Journal of Accounting and Economics, 31(1-3), 77-104. DOl: https://doi.org/10.1016/S0165-4101(01)00019-2

Barth, M. E., Landsman, W. R., \& Lang, M. H. (2008). International accounting standards and accounting quality. Journal of Accounting Research, 46(3), 467-498. DOI: https://doi.org/10.1111/j.1475-679X.2008.00287.x

Barth, M. E., Li, K. \& McClure, C., (2019). Evolution in value relevance of accounting information. Stanford University Graduate School of Business Research. Paper no. 17-24. DOI: http://dx.doi.org/10.2139/ssrn.2933197

Beaver, W. H. (1968). Alternative accounting measures as predictors of failure. The Accounting Review, 43(1), 113-122.

Braga, P. G. da S., Carmo, C. H. S. do, \& Cunha, M. F. da. (2021). Value relevance: efeitos das especificidades contábeis das empresas brasileiras do segmento de construção civil e incorporação imobiliária. Revista Ambiente Contábil, 13(1), 134-150. DOl: $\quad$ https://doi.org/10.21680/21769036.2021 v13n1ID19894

Brown, S., Lo, K., \& Lys, T. (1999). Use of R2 in accounting research: measuring changes in value relevance over the last four decades. Journal of Accounting and Economics, 28(2), 83-115. DOl: https://doi.org/10.1016/S01654101 (99)00023-3

Brugni, T. V., Rodrigues, A., Cruz, C., \& Szuster, N. (2012). IFRIC 12, ICPC 01 e contabilidade regulatória: influências na formação de tarifas do setor de energia elétrica. Sociedade, Contabilidade e Gestão, 7(2), 104-119.

Cappellesso, G., Rocha, L. C. N., \& Dantas, J. A. (2018). Value Relevance da Perda por Redução ao Valor Recuperável do Goodwill: Evidências das 
Empresas Listadas na BM\&FBovespa. Contabilidade Vista \& Revista, 29(3), 102-120. DOl: https://doi.org/10.22561/cvr.v29i3.4276

Carvalho, E. S., Wanderley, C. A., Libonati, J. J., \& Santos, A. H S. (2014). Um estudo comparativo entre indicadores econômico-financeiros, baseados na Contabilidade Regulatória e nas normas contábeis internacionais das empresas de distribuição de energia do setor elétrico brasileiro. Registro Contábil, 5(3), 20-40.

Collins, D. W., Maydew, E. L., \& Weiss, I. S. (1997). Changes in the value-relevance of earnings and book values over the past forty years. Journal of Accounting and Economics, 24(1), 39-67. DOI: https://doi.org/10.1016/S01654101 (97)00015-3

Comitê de Pronunciamentos Contábeis - CPC. (2014). Orientação OCPC 08: Reconhecimento de determinantes ativos e passivos nos relatórios contábilfinanceiros de propósito geral das distribuidoras de energia elétrica. Recuperado de http://www. cpc. org. br. Acesso em fevereiro de 2020.

Corrêa, A. C. C., Neto, A. A., Nakao, S. H., \& Osajima, A. A. (2012). A relevância da informação contábil na identificação de empresas criadoras de valor: um estudo do setor de energia elétrica brasileiro. Revista Contemporânea de Contabilidade, 9(18), 137-166. DOI: http://dx.doi.org/10.5007/21758069.2012v9n18p137

Dechow, P., Ge, W., \& Schrand, C. (2010). Understanding earnings quality: A review of the proxies, their determinants and their consequences. Journal of Accounting and Economics, 50(2-3), 344-401. DOI: https://doi.org/10.1016/j.jacceco.2010.09.001

Ermel, M. D. A., \& Do Monte, P. A. (2018). Controle acionário, remuneração de executivos e desempenho empresarial: Evidências para 0 mercado brasileiro. Revista Brasileira de Finanças, 16(3), 455-491. DOI: http://dx.doi.org/10.2139/ssrn.2963481

Fávero, L. P., \& Belfiore, P. (2017). Manual de análise de dados: estatística e modelagem multivariada com Exce/®, SPSS ${ }^{\circledR}$ e Stata ${ }^{\circledR}$ (1. Ed.). Rio de janeiro: Elsevier Brasil.

Ferreira, M. P., Carmo, C. H. S. do, \& Ribeiro, A. M. (2020). A value relevance dos ativos financeiros das empresas do setor elétrico brasileiro. Enfoque: Reflexão Contábil, 39(3), 85-98. DOI: https://doi.org/10.4025/enfoque.v39i3.45906

Flores, E., \& Lopes, A. B. (2019). Decréscimo na Relevância da Informação Contábil das Distribuidoras de Energia Elétrica no Brasil no Período PósIFRS. Revista Brasileira de Gestão de Negócios, 21 (4), 928-952. DOl: https://doi.org/10.7819/rbgn.v21i5.4023 
Francis, J., \& Schipper, K. (1999). Have Financial Statements Lost Their Relevance? Journal of Accounting Research, 37(2), 319-352. DOI: https://doi.org/10.2307/2491412

Gonçalves, J. C., Batista, B. L. L., Macedo, M. A. S., \& Marques, J. A. V. C. (2014). Análise do impacto do processo de convergência às normas internacionais de contabilidade no Brasil: um estudo com base na relevância da informação contábil. Revista Universo Contábil, 10(3), 25-43. DOI: https://doi.org/10.4270/RUC.2014318

Gonçalves, K. A., Conegliam, L., \& do Carmo, C. H. S. (2017). Value Relevance das Propriedades para Investimento: Evidência do Mercado de Capitais Brasileiro. Revista Contabilidade, Gestão e Governança,20(1), 2-19. DOI: http://dx.doi.org/10.21714/1984-3925_2017v20nlal

Guia, L. D., \& Dantas, J. A. (2020). 'Value Relevance' dos Ativos Fiscais Diferidos na Indústria Bancária Brasileira. Revista Contabilidade \& Finanças, 31 (82), 3349. DOI: https://doi.org/10.1590/1808-057×201808060

Hadi, A. S. (1994). A modification of a method for the detection of outliers in multivariate samples. Journal of the Royal Statistical Society: Series B (Methodological), 56(2), 393-396.

Hoppe, A. A. (2012). Estudo sobre as diferenças de práticas contábeis nas demonstrações contábeis societárias e regulatórias de distribuidoras de energia elétrica no Brasil (Dissertação de Mestrado). Pontifícia Universidade Católica de São Paulo, São Paulo, São Paulo, Brasil.

Hungarato, A., \& Lopes, A. B. (2008). Value relevance dos gastos em P\&D para o preço das ações das empresas brasileiras negociadas na Bovespa. Simpósio de Gestão da Inovação Tecnológica, Brasília, Brasil, XXV.

IFRS. (2018). Why global accounting standards? Recuperado em 11 de janeiro, 2021, de: <https://www.ifrs.org/use-around-the-world/why-globalaccounting-standards/>.

La Porta, R., Lopez-de-Silanes, F., Shleifer, A., \& Vishny, R. W. (2000). Agency problems and dividend policies around the world. The Journal of Finance, 55(1), 1-33. DOI: https://doi.org/10.1111/0022-1082.00199

Lima, J. B. N. D. (2010). A relevância da informação contábil e o processo de convergência para as normas IFRS no Brasil (Tese de Doutorado). Universidade de São Paulo, São Paulo, São Paulo, Brasil. https://www.teses.usp.br/teses/disponiveis/12/12136/tde-24032011185955/publico/JoaoBatistaNastdeLIma.pdf

Loch, M., Silva, J. C., Bueno, G., \& Marcon, R. (2020). O Governo como Acionista e o Conflito Principal-Principal no Setor Elétrico Brasileiro. Brazilian Business Review, 17(1), 24-45. DOI: http://dx.doi.org/10.15728/bbr.2020.17.1.2 
Lopes, A. B., \& Iudícibus, S. D. (2012). Teoria Avançada da Contabilidade. São Paulo: Atlas.

Lopes, A. B., de Sant'Anna, D. P., \& Costa, F. M. (2007). A relevância das informações contábeis na Bovespa a partir do arcabouço teórico de Ohlson: avaliação dos modelos de Residual Income Valuation e Abnormal Earnings Growth. Revista de Administração, 42(4), 497-510. DOI: https://doi.org/10.1590/S0080-21072007000400009

Macedo, M. A. S., Machado, M. R., Machado, M. A. V., \& Mendonça, P. H. C. (2013). Impacto da Conversão às normas Contábeis Internacionais no Brasil Sobre o Conteúdo Informacional da Contabilidade. Revista de Educação e Pesquisa em Contabilidade, 7(3), 222-239. DOI: https://doi.org/10.17524/repec.v7i3.905

Macedo, M. A. S., Machado, M. A. V., Murcia, F. D. R., \& Machado, M. R. (2011). Análise do impacto da substituição da DOAR pela DFC: um estudo sob a perspectiva do value-relevance. Revista Contabilidade \& Finanças, 22 (57), 299-318. DOI: https://doi.org/10.1590/S1519-70772011000300005

Malkiel, B. G., \& Fama, E. F. (1970). Efficient capital markets: A review of theory and empirical work. The Journal of Finance, 25(2), 383-417. DOI: https://doi.org/10.1111/j.1540-6261.1970.tb00518.x

Martins, V. G., Machado, M. A. V., \& Callado, A. L. C. (2014). Relevância e representação fidedigna na mensuração de ativos biológicos a valor justo por empresas listadas na BM\&FBovespa. Revista Contemporânea de Contabilidade, 11 (22), 163-188. DOl: https://doi.org/10.5007/21758069.2014v1 ln22p163

Martins, V. G., Machado, M. A. V., \& Machado, M. R. (2013). Value Relevance das informações de Leasing Operacional: um estudo em empresas brasileiras. Enfoque: Reflexão Contábil, 32(2), 83-99. DOl: https://doi.org/10.4025/enfoque.v32i2.19762

Medeiros, J. A., Wanderley, C. A., Araújo, A., \& Santos, E. D. S. C. (2013). Um estudo sobre o nível de comparabilidade entre os valores contábeis regulatórios e societários das companhias brasileiras de distribuição de energia elétrica. Anais do Congresso UFPE de Ciências Contábeis, Pernambuco, Brasil, $6^{\circ}$.

Moura, G. D., Fank, O. L., \& Varela, P. S. (2012). Evidenciação dos ativos intangiveis pelas empresas do setor de energia elétrica listadas na BM\&FBOVESPA. Contabilidade, Gestão e Governança, 15(1), 17-32.

Ohlson, J. A. (1995). Earnings, book values, and dividends in equity valuation. Contemporary Accounting Research,11(2), 661-687. DOl: https://doi.org/10.1111/j.1911-3846.1995.tb00461.x 
Peltzman, S. (1976). Toward a more general theory of regulation. The Journal of Law and Economics, 19(2), 21 1-240. DOI: https://doi.org/10.1086/466865

Pereira, V., Santana, A., Mendes, F., \& Khan, A. (2008). Análise do setor de energia elétrica do estado do Pará: uma aplicação da matriz de insumoproduto. Amazônia: Ciência \& Desenvolvimento, 4(7), 7-26.

Pinto, A. F., Avelar, B., Fonseca, K. B. C., Silva, M. B. A., \& Costa, P. D. S. (2014). Value relevance da evidenciação de provisões e passivos contingentes. Pensar Contábil, 16(61), 54-65.

Rezende, A. J. (2005). A relevância da informação contábil no processo de avaliação de empresas da nova e velha economia-uma análise dos investimentos em ativos intangíveis e seus efeitos sobre value-relevance do Iucro e patrimônio líquido. BBR-Brazilian Business Review, 2(1), 33-52.

Sami, H., \& Zhou, H. (2004). A comparison of value relevance of accounting information in different segments of the Chinese stock market. The International Journal of Accounting,39(4), 403-427. DOI: https://doi.org/10.1016/j.intacc.2004.08.001

Santos, A. A., Botinha, R. A., \& Lemes, S. (2019a). Análise da value relevance da demonstração do valor adicionado nos níveis diferenciados de governança corporativa da BM\&FBOVESPA. Revista Catarinense da Ciência Contábil, 18, 1-16. DOI: https://doi.org/10.16930/2237-766220192697

Santos, O. M., \& Silva, P. D. A. (2014). Os métodos contábeis dos esforços bemsucedidos capitalização total: um estudo sob a perspectiva do Value Relevance. Enfoque: Reflexão Contábil, 33(2), 121-138. DOI: https://doi.org/10.4025/enfoque.v33i2.22307

Santos, S. M. D., Lemes, S., \& Barboza, F. L. M. (2019b). O Value Relevance é Relevante? Revista de Contabilidade e Organizações, 13(2), 1-18. DOI: http://dx.doi.org/10.11606/issn.1982-6486.rco.2019.152518

Suzart, J. A. D. S., Souza, V. D., Carvalho, A. S., Rivas, E. D., \& Martins, E. (2012). Informações societárias versus informações regulatórias: uma análise da relevância da informação contábil no contexto das concessionárias brasileiras do setor elétrico. In: Anais do Congresso USP de Controladoria e Contabilidade, São Paulo, Brasil, $12^{\circ}$. 


\section{CONTRIBUIÇÕES DOS AUTORES}

\begin{tabular}{|l|c|c|c|c|}
\hline \multicolumn{1}{|c|}{ Contribuição } & $\begin{array}{c}\text { Marília } \\
\text { Paranaíba } \\
\text { Ferreira }\end{array}$ & $\begin{array}{c}\text { Alex } \\
\text { Mussoi } \\
\text { Ribeiro }\end{array}$ & $\begin{array}{c}\text { Jackelline } \\
\text { Ferreira Cordeiro } \\
\text { Milhomem }\end{array}$ & $\begin{array}{c}\text { Carlos } \\
\text { Henrique } \\
\text { Silva do } \\
\text { Carmo }\end{array}$ \\
\hline $\begin{array}{l}\text { 1. Idealização e concepção do } \\
\text { assunto e tema da pesquisa }\end{array}$ & & & & $\checkmark$ \\
\hline $\begin{array}{l}\text { 2. Definição do problema de } \\
\text { pesquisa }\end{array}$ & $\checkmark$ & $\checkmark$ & & $\checkmark$ \\
\hline $\begin{array}{l}\text { 3. Desenvolvimento da } \\
\text { Plataforma Teórica }\end{array}$ & $\checkmark$ & $\checkmark$ & & \\
\hline $\begin{array}{l}\text { 4. Delineamento da abordagem } \\
\text { metodológica da pesquisa }\end{array}$ & $\checkmark$ & & $\checkmark$ & $\checkmark$ \\
\hline 5. Coleta de dados & $\checkmark$ & $\checkmark$ & $\checkmark$ & $\checkmark$ \\
\hline $\begin{array}{l}\text { 6. Análises e interpretações dos } \\
\text { dados coletados }\end{array}$ & $\checkmark$ & $\checkmark$ & $\checkmark$ & $\checkmark$ \\
\hline 7. Conclusões da pesquisa & $\checkmark$ & $\checkmark$ & & \\
\hline 8. Revisão crítica do manuscrito & $\checkmark$ & & & $\checkmark$ \\
\hline $\begin{array}{l}\text { 9. Redação final do manuscrito, } \\
\text { conforme as normas } \\
\text { estabelecidas pela Revista. }\end{array}$ & & $\checkmark$ & & \\
\hline 10. Orientação & & & & \\
\hline
\end{tabular}

